\title{
ARCHITECTURAL STRATEGIES THAT PROMOTE CREATION OF SOCIAL BONDS WITHIN ECO-NEIGHBOURHOODS
}

\section{STRATEGIE ARCHITEKTONICZNE PROMUJĄCE TWORZENIE WIĘZI SPOKECZNYCH NA TERENIE EKOOSIEDLI}

\author{
Monika Trojanowska \\ dr inż. arch. \\ Author's ORCID number: 0000-0001-8168-0746 \\ UTP Uniwersytet Technologiczno-Przyrodniczy w Bydgoszczy \\ Wydział Budownictwa, Architektury i Inżynierii Środowiska \\ Zakład Architektury i Urbanistyki
}

\begin{abstract}
Modern eco-neighbourhoods are designed to implement the 3e principles: ecology - equality economy. The ecological aspects require harmony with nature and people. The equality concept stipulates living together in the environment which stimulates individual growth and well-being. The economic aspects encompasses promotion of short-distances circular economy, securing employment for the inhabitants and limiting wasteful spending. The goal of those principles is to create the neighbourhoods, where the well-being of inhabitants is promoted. This paper discusses how the designed environment based on $3 e$ principles can influence the creation of community engagement, social bonds and social capital.
\end{abstract}

Key words: community engagement, architecture, urban design, eco-neighbourhoods, inclusive public space, social space.

\section{STRESZCZENIE}

Współczesne eko-dzielnice mają realizować zasady 3e: ekologia - ekorówność - ekonomia. Aspekty ekologiczne wymagają harmonii z naturą i ludźmi. Koncepcja równości zakłada wspólne życie w środowisku, które stymuluje rozwój i dobre samopoczucie jednostki. Aspekty ekonomiczne obejmują promocję gospodarki krótkich dystansów o obiegu zamkniętym, zapewnienie miejsc pracy mieszkańcom oraz ograniczenie marnotrawstwa. Celem tych zasad jest tworzenie dzielnic w trosce o dobrobyt mieszkańców. W artykule omówiono, jak środowisko zaprojektowane w oparciu o zasady 3e może wpłynąć na tworzenie więzi społecznych i kapitału społecznego na przykładach z ekoosiedli w Europie.

Słowa kluczowe: architektura, urbanistyka, ekoosiedla, włączająca przestrzeń publiczna, przestrzeń kontaktów społecznych. 


\section{INTRODUCTION}

Architecture and urban planning have always been regarded as a vehicle for better future. The mission of constructing a new improved environment for human beings is now extended with principles of sustainable development. The concept of 3e principles: ecology - equality - economy relies on human factor more than any others. The ecological aspects of architecture and urban planning require harmony with nature and other people. The equality concept stipulates living together in an environment that stimulates individual growth and well-being. The economic aspects encompass the promotion of short-distances circular economy, securing employment for the inhabitants, and limiting wasteful spending. Bringing forth a new place for a living should come with the construction of a better society. All of the three dynamics of Sustainable Communities: Economy, Ecology, and Equity are linked with social capital. Today the way of putting forward those dynamics in one place is the creation of eco-neighborhoods. What has started in the mid-20 century with the grassroots bottom-up phenomenon, today is gaining popularity all over the planet. There are examples of eco-neighborhoods implemented and well-functioning in all parts of the world and both hemispheres.

In this paper we focus on the social aspects and the importance of equity in design and management of eco-neighbourhoods. The research question is what are the architectural solutions which can be engaged to stimulate the creation of friendly social habitat within sustainable urban tissue?

There were numerous attempts to create a perfect place for living. However Dragos Stefan Dascalu (2013) draws the attention to the fact that: It is a true paradox (one that is found in many if not all utopias), that trying to create a new and perfect society leads to an opposite, perverse effect, that of creating a totalitarian, repressive, socially homogenous society. Today, the new idea for putting the concept of $3 e$ principles into action for the well being of people is the creation of econeighbourhoods. However, the lessons from the past must be learnt, that the most important factors are the social capital and the social bonds relative to Community Engagement.

\section{METHOD}

In the first part of the paper, the literature review is presented, followed presentation of the introduction of a new category to the universal standard for health-promoting places created by the author.

The first question was how to define the social capital and social bonds and examine the influence that architecture can have upon its creation. The concept of social capital dates back to the XIX century. Pierre Bourdieu considered social capital as a form of economic capital, which can be accumulated, transmitted, and reproduced over time (Dascalu, 2013). Robert Putnam argues that social capital is a form of public good linked to lower crimes rate, higher altruism, and improvement of health (ibidem, Dascalu, 2013; Putnam, 2000). Dragos Stefan Dascalu (2013) refers to social capital as social networks built on reciprocity and trust. He lists empowerment of individuals, social equality, level of information and knowledge, and the quality of previous cooperative experiences as a mechanism the creation of social capital relies on and argues that the architecture understood as object or space could not fulfill that role. The built form, spatial configurations, or architecture understood as an object has in fact very little impact on social capital. We need to shift the paradigm to the processual approach of architecture regarded as dispositive which can stimulate building trust-based relationships between individuals and thus can stimulate the appearance of social capital. To fulfil that role, architecture is understood as an ensemble of factors relating to building space: norms, laws, use, function, process, practice. Only a dispositive approach to architecture can make a difference (Dascalu, 2013).

The objective of this study was to determine ways how can architecture stimulate community engagement, creation of social bond and appearance of social capital. 


\subsection{Discussion}

Building social capital is an incremental and cumulative process and that can lead to a very long process (Dascalu, 2013). The crucial factor in that process is trust, which depend on a series of mechanisms. Dragos Stefan Dascalu (2013) mentioned the empowerment of individuals, social equality, level of information and knowledge and the quality of previous cooperative experience as the most important. The economic equity encompassing the level of income, the standard of living is fundamental for building a trusting community. The more equitable an economy is, the higher the level of generalized trust will be (Dascalu, 2013).

Architecture, although has no magic to make good people out of negative characters, could, to some extent, provokes certain effects on human behaviour. The architectural form can, in certain conditions, permit or obstruct certain actions. However, it cannot be studied independently from the entire network (Dascalu, 2013). There are few strategies, mentioned in the literature, that can be employed to facilitate the creation of social capital:

- Personalising the architectural process

- Participation of all stakeholders, including inhabitants and users

- Determining the rules of conduct and self-management

- Space for social contact

- Third places

- Fourth places

\section{Personalising the architectural process}

To trust someone people need to get to know them. Dragos Stefan Dascalu (2013) specified that: In order to build trust relations, all agents in the dispositive must be physically present, open for developing a relation and offering opportunities for testing trust. That is not usual, as many architects prefer to determine the function in the name of the potential users, based on a deduction of necessity. Routinely the stakeholders prefer to decide in the name of other individuals what is necessary for them. In the case of modern neighbourhoods that may seem logical, since the future inhabitants are in most cases unknown. However, the other agents (architects, local government, financing agents, users from the entire neighbourhoods, builders, initiators, clients, etc.) are easy to identify and should get to know each other well. That course of action, when all the stakeholders are working together from the very beginning of the investing process is called Integrated Design and is a trademark of operationalisation of principles of sustainable development in architecture. It means that the process has to be designed in such a way that these agents can meet each other and present themselves as individuals and not as institutions (Dascalu, 2013). That, highly localised approach is the foundation of Integrated Design.

\section{Participation of all stakeholders, including inhabitants and users}

The social capital forms in a strong empowered community, among citizens with a high sense of community. One empowerment exercise usually leads to more ambitious goals. Citizens who are aware that they can make things happen if they work together are building stronger bonds of social capital. The concept of public participation refers to enabling citizens to participate in the activities of public administration entities and influence of "minorities" on the decision of those who manage (Bednarska-Olejniczak, Olejniczak \& Svobodová, 2019). Community participation processes lead to a shared responsibility in decision making (Amado et al., 2009). Public participation is a process by which public concerns, needs and values are incorporated into decision-making procedures, and as such requires subsequent stages (inform the public, listen to the public, engage in problem solving, develop agreements). (Bednarska-Olejniczak, Olejniczak \& Svobodová, 2019). For the formation of social capital it is most advantageous to include the participation of the population right from the start of the planning process. Community participation enabled that the intervention area resources (human, natural, economic and cultural) are valued by the local agents and thus constitute the basis for the creation of proposed new sustainable activities, developing employment and wealth, preserving natural values and promoting an appropriation of public space with greater so- 
cial sensitivity and responsibility (Amado et al., 2009). Public participation itself require promoting citizens' initiatives, empowering people's organizations, and strengthening local democracy. (Bednarska-Olejniczak, Olejniczak \& Svobodová, 2019). Thus it may include a very wide range of activities and tools: participative budget, civic legislative initiative, activating measures (picnics, cultural activities etc.), survey research, study works (workshops, laboratories, on-line consultations), the promotion of good practices etc.).

\section{Determining the rules of conduct and self-management}

The organic development of grassroots democracy may stimulate the creation of community social capital. The direct participation of the individual users in creating the rules and enforcing them is essential to the trust building process (Dascalu, 2013). The governance which applies innovative methods of consultation that strengthen civil society is highly envisioned. The construction of econeighbourhoods requires the creation of an integrated system for managing urban strategies and urban programs. The should be some priorities. For example the strategy for Wrocław 2030 stipulates actions divided into seven priorities: mobility, quality of the environment and urban space, entrepreneurship, creative and innovative economy connected with science, healthy and active residents, governance and open city. The quality of the environment and urban space is linked among others to promoting space sharing and increasing safety in public areas. The governance openly calls for the organic development of grassroots democracy, especially within housing estates (Bednarska-Olejniczak, Olejniczak \& Svobodová, 2019)

\section{Space for social interactions}

The Ray Oldenburg theory (1989) distinguishes certain categories of social places: 'first places' are our homes, 'second places' - workplaces for adults or schools for children, and the 'third places' which are defined as chosen places for socializing, important for the individual human being. 'Third places' are characterized by a radical departure from the routines of home and work, inclusivity and social comfort (Simões Aelbrecht 2016). Among the 'third places' we can list: churches, cultural centres, art galleries, cafes, coffee shops, beauty saloons and barber shops respectively for ladies and gentleman, workshops for tinkers, sport facilities etc. A well-designed public park can also fulfil the role of a third place, especially if equipped with some kind of a heated shelter during colder days.

Patricia Simões Aelbrecht (2016) added a category of 'fourth places' as an additional category of informal social settings alongside 'third places'. 'Fourth places' are described by 'in-betweenness' in terms of spaces, activities, time and management, as well as a great sense of publicness. They are more open, socially diverse and inclusive to bring strangers together. Patricia Simões Aelbrecht defining 'fourth places' mentioned all other than traditional public spaces such as streets and squares and 'third places' informal gathering spaces in the city, mainly intermediate and leftover spaces e.g.: street intersections, stoops, edge spaces, bus stops and waiting spaces as well as thresholds. Therefore 'fourth places' allow for all activities which are in-between necessary activities: 'people-watching', waiting and 'killing time', thus encouraging interaction among a diverse set of users. People use those spaces to stand, talk, sit, and watch other people; therefore, those spaces increase chances of intimate interaction.

Majd Al-Homoud and Louis G. Tassinary (2004) conducted research that evidenced that there is a small set of attributes of space enclosure components of single family homes as potential moderators of patterns of social interaction. That research evidence may suggest guidelines for the design of 'fourth places'. Al-Hamoud and Tassinary studied transition zones - intermediate areas between home and neighborhood, physically and psychologically. They called them transaction locations, such as the front yard, driveways, paths, porches, entrances, and the front steps. Researchers found that people use them as both bridges between themselves and their immediate local community and as regulators of their social interaction. They are perceived as intermediate areas between home and neighborhood, physically and psychologically. The 'fourth places' - transitional spaces are valuable in the context of personal support, probably because of the activities that take place in these spaces. However, to bridge social bonds the transitional spaces need territorial 
markers, such as landscaping, decorating (including yard furnishing), signs, and fencing. Especially plantings and decorations encourage residents to interact with each other. The presence of territorial markers signifies social support, as they are initial symbolic interactions media. Those markers facilitate interaction reactions. On the other hand, overuse of territorial markers promotes social exclusion and isolation. Thus, the research evidence suggests that the house and the front yard are two entities to be designed as one, where each serves the other and together provide a complete private, yet approachable, sphere for the residents. (Al-Hamoud and Tassinary, 2004)

Both 'third places' and 'fourth places' are crucial to support the informal social life of econeighbourhoods (Fig. 1, 2).

Fig. 1. Friendly public space in the suburbs of Paris, France. Example of 'third place' for toddlers and 'fourth place' for residents. Source: Monika Trojanowska, 2015

Ryc. 1. Przyjazna przestrzeń publiczna na przedmieściach Paryża, Francja. Przykład "miejsca trzeciego" dla dzieci "miejsca czwartego" dla mieszkańców. Żródło: Monika Trojanowska, 2015

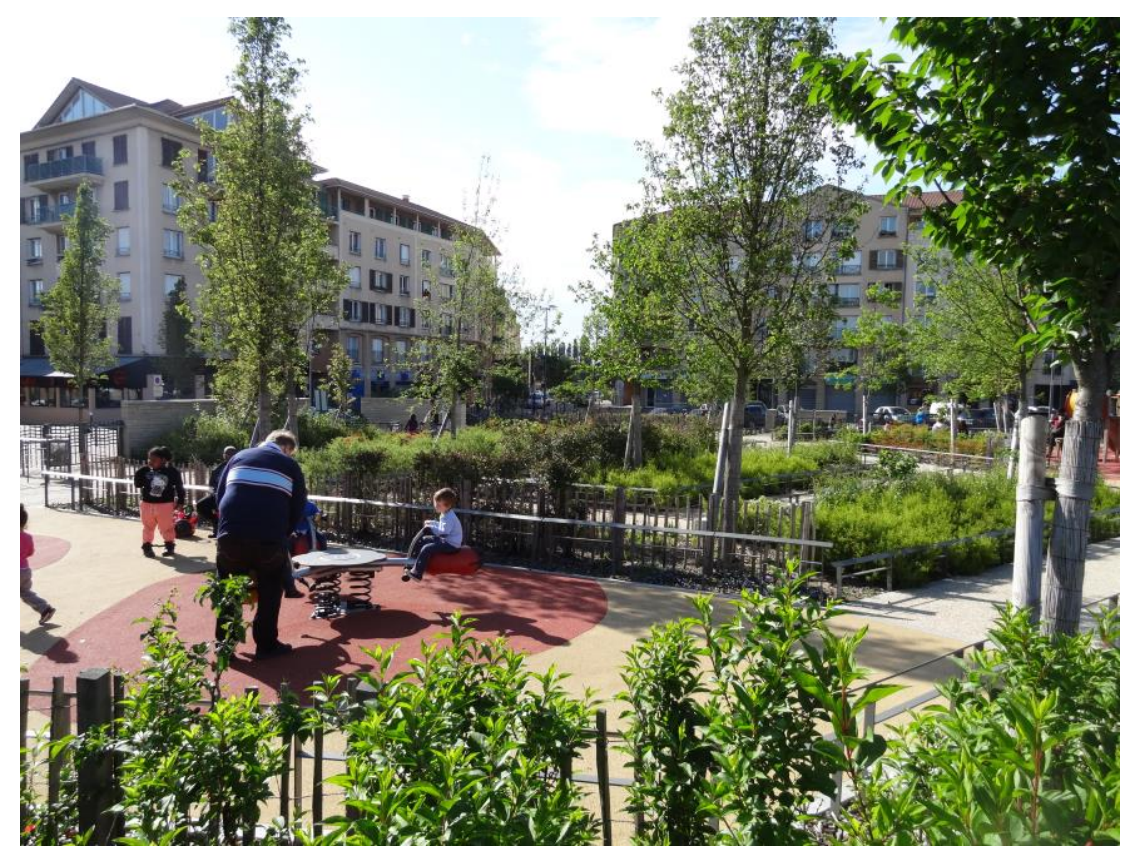

Fig. 2. Garnizon, Example of 'third place' and 'fourth place' for residents Gdańsk. Source: M. Trojanowska, 2020

Ryc. 2. Garnizon, Gdańsk Przykład "miejsca trzeciego" i "miejsca czwartego" dla mieszkańców Żródło: M. Trojanowska, 2020

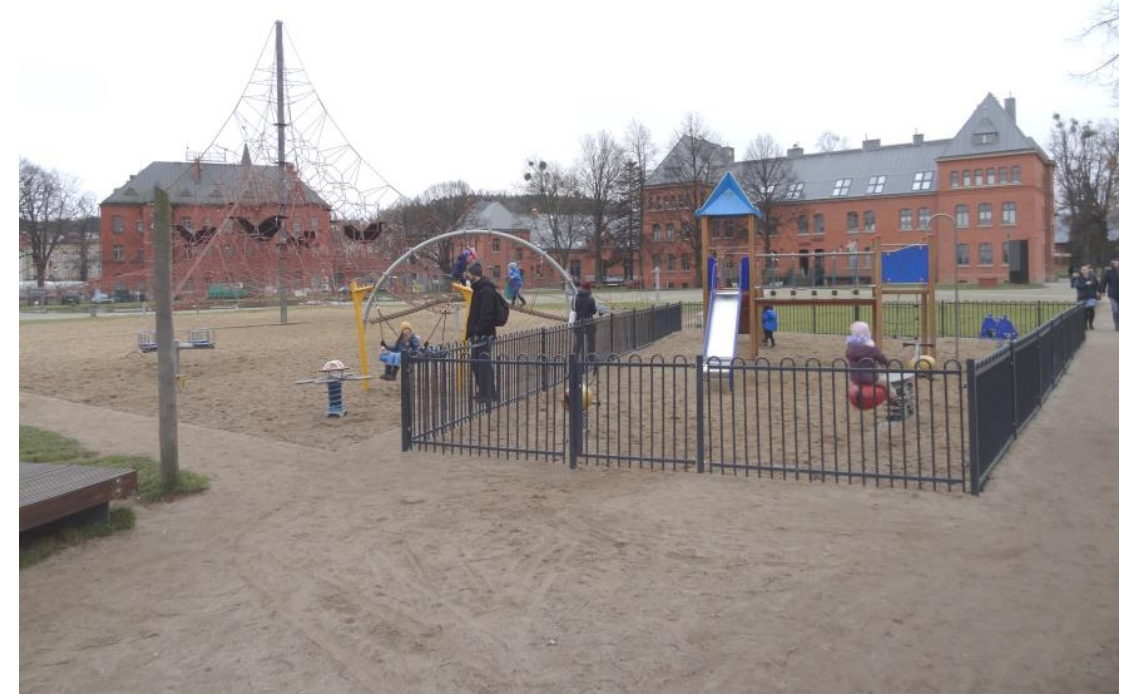




\subsection{EXAMPLES OF ECO-NEIGHBOURHOODS}

The results of literature review were verified in existing neighbourhoods. Six neighbourhoods were chosen, three with official certificates and labels, and three others individually assessed as econeighbourhoods by the author with own methods (Trojanowska, 2020) (Tab. 1).

Table 1. Overview of selected neighbourhoods. Source: Author

\begin{tabular}{|l|l|l|l|}
\hline & CERTIFICATE & GENERAL OVERVIEW & OWNERSHIP \\
\hline $\begin{array}{l}\text { ZAC CLICHY } \\
\text { BATIGNOLLES, } \\
\text { PARYŻ }\end{array}$ & ECOQUARTIER & $\begin{array}{l}\text { centrally located in densely populated district, city } \\
\text { centre of large metropolis, urban revitalisation of for- } \\
\text { merly industrial site }\end{array}$ & $\begin{array}{l}\text { privately own } \\
\text { flats/ commercial } \\
\text { space// social } \\
\text { housing //public } \\
\text { property }\end{array}$ \\
\hline $\begin{array}{l}\text { ZAC DOCKS DE } \\
\text { SAINT OUEN, } \\
\text { SAINT OUEN }\end{array}$ & ECOQUARTIER & $\begin{array}{l}\text { suburbian outskirts of large metropolis, urban revitali- } \\
\text { sation of formerly industrial site }\end{array}$ & $\begin{array}{l}\text { privately own } \\
\text { flats/ commercial } \\
\text { space // social } \\
\text { housing//public } \\
\text { property }\end{array}$ \\
\hline $\begin{array}{l}\text { HAMMARBY SJO- } \\
\text { STAD } \\
\text { SZTOKHOLM }\end{array}$ & ECO-CITY & $\begin{array}{l}\text { suburban outskirts of large city, urban revitalisation of } \\
\text { formerly industrial site }\end{array}$ & $\begin{array}{l}\text { privately own } \\
\text { flats/ commercial } \\
\text { space //public } \\
\text { property }\end{array}$ \\
\hline $\begin{array}{l}\text { RIVERVIEW } \\
\text { GDAŃSK }\end{array}$ & LEED & $\begin{array}{l}\text { historic city centre, urban revitalisation of fragment of } \\
\text { historic district destroyed during WW2 }\end{array}$ & $\begin{array}{l}\text { privately own } \\
\text { flats/ commercial } \\
\text { space }\end{array}$ \\
\hline $\begin{array}{l}\text { GARNIZON } \\
\text { GDAŃSK }\end{array}$ & NO LABEL & historic district, urban revitalisation of military caserns & $\begin{array}{l}\text { privately own } \\
\text { flats/ commercial } \\
\text { space }\end{array}$ \\
\hline $\begin{array}{l}\text { OSIEDLE FI } \\
\text { KRAKÓW }\end{array}$ & NO LABEL & historic district, urban revitalisation of brownfield & $\begin{array}{l}\text { privately own } \\
\text { flats/ commercial } \\
\text { space }\end{array}$ \\
\hline
\end{tabular}

The selected neighbourhoods were analysed using the methodology previously prepared (Trojanowska, 2017; 2020) but applied to new attributes related to Community Engagement.

- Personalising the architectural process

- Participation of all stakeholders, including inhabitants and users

- Determining the rules of conduct and self-management

- Space for social contact

- Third places

- Fourth places

To rate the presence of attributes (using numbers) the following scale was used:

1 - the attribute was present and its potential was being used well,

0.5 - the attribute was present but some reservations applied,

0 - the attribute was not present.

The enhanced rating (by adding the 0.5 value) was used to mitigate whether an attribute's potential was fully used or some reservations applied (Tab. 2). 
Table 2. Rating the presence of attributes related to community engagement within selected neighbourhoods. Source: Author

\begin{tabular}{|c|c|c|c|c|c|c|}
\hline & $\begin{array}{l}\text { ZAC CLICHY } \\
\text { BATIGNOLLES, } \\
\text { PARYŻ }\end{array}$ & $\begin{array}{l}\text { ZAC } \\
\text { DOCKS DE } \\
\text { SAINT } \\
\text { OUEN, } \\
\text { SAINT } \\
\text { OUEN }\end{array}$ & $\begin{array}{l}\text { HAMMARBY } \\
\text { SJOSTAD } \\
\text { SZTOKHOLM }\end{array}$ & $\begin{array}{l}\text { RIVERVIEW } \\
\text { GDAŃSK }\end{array}$ & $\begin{array}{l}\text { GARNIZON } \\
\text { GDAŃSK }\end{array}$ & $\begin{array}{l}\text { OSIEDLE FI } \\
\text { KRAKÓW }\end{array}$ \\
\hline \multicolumn{7}{|l|}{ PLACEMAKING } \\
\hline $\begin{array}{l}\text { COMMUNITY } \\
\text { ENGAGEMENT }\end{array}$ & TOTAL (6) & TOTAL (6) & TOTAL (6) & TOTAL $(5,5)$ & TOTAL (6) & TOTAL $(5,5)$ \\
\hline $\begin{array}{l}\text { Personalising the } \\
\text { architectural } \\
\text { process }\end{array}$ & YES (1) & YES (1) & YES (1) & YES (1) & YES (1) & YES (1) \\
\hline $\begin{array}{l}\text { Participation of all } \\
\text { stakeholders, } \\
\text { including inhabit- } \\
\text { ants and users }\end{array}$ & $\begin{array}{l}\text { YES (1) } \\
\text { participatory } \\
\text { design process, } \\
\text { integrated design }\end{array}$ & $\begin{array}{l}\text { YES (1) } \\
\text { participatory } \\
\text { design } \\
\text { process, } \\
\text { integrated } \\
\text { design }\end{array}$ & $\begin{array}{l}\text { YES (1) } \\
\text { participatory } \\
\text { design pro- } \\
\text { cess, integrat- } \\
\text { ed design }\end{array}$ & $\begin{array}{l}\text { NO }(0) \\
\text { flats for sale } \\
\text { to anony- } \\
\text { mous clients } \\
\text { after comple- } \\
\text { tion }\end{array}$ & $\begin{array}{l}\text { NO }(0) \\
\text { flats for sale } \\
\text { to anony- } \\
\text { mous clients } \\
\text { after com- } \\
\text { pletion }\end{array}$ & $\begin{array}{l}\text { NO (0) } \\
\text { flats for sale to } \\
\text { anonymous } \\
\text { clients after } \\
\text { built }\end{array}$ \\
\hline $\begin{array}{l}\text { Determining the } \\
\text { rules of conduct } \\
\text { and self- } \\
\text { management }\end{array}$ & YES (1) & YES (1) & YES (1) & YES (1) & YES (1) & YES (1) \\
\hline $\begin{array}{l}\text { Space for social } \\
\text { contact }\end{array}$ & $\begin{array}{l}\text { YES (1) } \\
\text { dedicated space, } \\
\text { schools, cultural } \\
\text { centre }\end{array}$ & $\begin{array}{l}\text { YES (1) } \\
\text { dedicated } \\
\text { space, } \\
\text { schools, } \\
\text { cultural } \\
\text { centre }\end{array}$ & $\begin{array}{l}\text { YES (1) } \\
\text { dedicated } \\
\text { space, } \\
\text { schools, cul- } \\
\text { tural centre }\end{array}$ & $\begin{array}{l}\text { YES/NO } \\
(0,5) \\
\text { only privately } \\
\text { own cafes } \\
\text { and shops }\end{array}$ & $\begin{array}{l}\text { YES (1) } \\
\text { dedicated } \\
\text { space, } \\
\text { cultural } \\
\text { centre }\end{array}$ & $\begin{array}{l}\text { YES/NO }(0,5) \\
\text { only privately } \\
\text { own cafes and } \\
\text { shops }\end{array}$ \\
\hline Third places & $\begin{array}{l}\text { YES (1) } \\
\text { cultural centre } \\
\text { privately own } \\
\text { cafes and shops }\end{array}$ & $\begin{array}{l}\text { YES (1) } \\
\text { cultural } \\
\text { centre } \\
\text { privately } \\
\text { own cafes } \\
\text { and shops }\end{array}$ & $\begin{array}{l}\text { YES (1) } \\
\text { cultural centre } \\
\text { privately own } \\
\text { cafes and } \\
\text { shops }\end{array}$ & $\begin{array}{l}\text { YES (1) } \\
\text { privately own } \\
\text { cafes and } \\
\text { shops cultur- } \\
\text { al centre } \\
\text { within walk- } \\
\text { ing distance }\end{array}$ & $\begin{array}{l}\text { YES (1) } \\
\text { cultural } \\
\text { centre } \\
\text { privately } \\
\text { own cafes } \\
\text { and shops }\end{array}$ & $\begin{array}{l}\text { YES (1) } \\
\text { privately own } \\
\text { cafes and } \\
\text { shops cultural } \\
\text { centre in close } \\
\text { distance to the } \\
\text { neighbourhood }\end{array}$ \\
\hline Fourth places & $\begin{array}{l}\text { YES (1) } \\
\text { universally ac- } \\
\text { cesible public } \\
\text { space }\end{array}$ & $\begin{array}{l}\text { YES (1) } \\
\text { universally } \\
\text { accesible } \\
\text { public space }\end{array}$ & $\begin{array}{l}\text { YES (1) } \\
\text { universally } \\
\text { accesible } \\
\text { public space }\end{array}$ & $\begin{array}{l}\text { YES (1) } \\
\text { universally } \\
\text { accesible } \\
\text { public space }\end{array}$ & $\begin{array}{l}\text { YES (1) } \\
\text { universally } \\
\text { accesible } \\
\text { public space }\end{array}$ & $\begin{array}{l}\text { YES (1) } \\
\text { universally } \\
\text { accesible } \\
\text { public space }\end{array}$ \\
\hline
\end{tabular}

\section{DISCUSSION. RESULTS}

\section{New attributes to be added to the UNIVERSAL STANDARD FOR HEALTH PROMOTING PLACES}

The results of the literature review were triangulated with studies of selected examples. The organisaztion of this study was divided in the same manner as the literature review, to include the strategies that can be employed to facilitate the creation of social capital. This study lead to the conclusion that the universal pattern should be expanded to include a category for the architectural attributes linked to creation to social bond in the category of 4 . Placemaking 


\section{Community Engagement}

- Personalising the architectural process

- Participation of all stakeholders, including inhabitants and users

- Determining the rules of conduct and self-management

- Space for social contact

- Third places

- Fourth places

Table 3. The universal standard for health promoting places.

Source: M.Trojanowska, 2017 with further changes

\begin{tabular}{|c|c|c|c|c|c|}
\hline \multicolumn{6}{|c|}{ UNIVERSAL STANDARD FOR HEALTH PROMOTING PLACES } \\
\hline \multicolumn{5}{|c|}{ UNIVERSAL STANDARD FOR THERAPEUTIC PARKS } & \multirow[b]{2}{*}{$\begin{array}{l}\text { 6. ACCESS TO } \\
\text { PARK }\end{array}$} \\
\hline $\begin{array}{l}\text { 1. UNIVER- } \\
\text { SAL DESIGN }\end{array}$ & $\begin{array}{l}\text { 2. PARK'S FUNC- } \\
\text { TIONAL PROGRAM }\end{array}$ & $\begin{array}{l}\text { 3. ORGANIZATION } \\
\text { OF SPACE AND } \\
\text { FUNCTIONS }\end{array}$ & $\begin{array}{l}\text { 4. PLACEMA- } \\
\text { KING }\end{array}$ & $\begin{array}{l}\text { 5. SUSTAI- } \\
\text { NA-BILITY }\end{array}$ & \\
\hline $\begin{array}{l}1.1 \text { Place } \\
\text { Area } \\
\text { Location } \\
\text { Surrounding } \\
\text { urban pattern } \\
1.2 \text { Environ- } \\
\text { mental char- } \\
\text { acteristics } \\
\text { Soil quality } \\
\text { Water quality } \\
\text { Air quality } \\
\text { Noise level } \\
\text { Biodiversity } \\
\text { Forms of } \\
\text { nature protec- } \\
\text { tion } \\
\text { 1.3 Universal } \\
\text { accessibility } \\
\text { (addressing } \\
\text { need of peo- } \\
\text { ple with disa- } \\
\text { bilities) } \\
1.4 \text { Access to } \\
\text { park } \\
\text { Distance to } \\
\text { potential } \\
\text { users } \\
\text { Public } \\
\text { transport } \\
\text { stops } \\
\text { Walkways to } \\
\text { park }\end{array}$ & $\begin{array}{l}\text { 2.1. Psychological } \\
\text { and physical regen- } \\
\text { eration } \\
\text { Natural Landscapes } \\
\text { Green open space } \\
\text { Place to rest in the } \\
\text { sun and in the shade } \\
\text { Place to rest in } \\
\text { silence and solitude } \\
\text { Possibility to ob- } \\
\text { serve other people } \\
\text { Possibility to ob- } \\
\text { serve animals } \\
\text { 2.2. Social Contacts } \\
\text { Enhancement } \\
\text { Organization of } \\
\text { events inside the } \\
\text { park } \\
\text { Gathering place for } \\
\text { groups } \\
\text { 2.3. Physical Activity } \\
\text { Promotion } \\
\text { Sports infrastructure } \\
\text { Recreational infra- } \\
\text { structure } \\
\text { Community gardens } \\
\text { 2.4. Catering for } \\
\text { basic needs } \\
\text { Safety and security } \\
\text { (presence of guards, } \\
\text { cleanness, mainte- } \\
\text { nance, etc.) } \\
\text { Places to sit and rest } \\
\text { Shelter } \\
\text { Restrooms } \\
\text { Drinking water } \\
\text { Food (possibility to } \\
\text { buy food in the park } \\
\text { or close vicinities) }\end{array}$ & $\begin{array}{l}\text { 3.1. The park spatial } \\
\text { composition follows } \\
\text { the surrounding urban } \\
\text { pattern } \\
\text { 3.2. Architectural } \\
\text { variety of urban envi- } \\
\text { ronment } \\
\text { Focal points and } \\
\text { landmarks } \\
\text { Structure of interiors } \\
\text { and connections } \\
\text { Long vistas (Extent) } \\
\text { Pathways with views } \\
\text { Invisible fragments of } \\
\text { the scene (Vista en- } \\
\text { gaging the imagina- } \\
\text { tion) } \\
\text { Mystery, Fascination } \\
\text { Framed views } \\
\text { Human scale } \\
\text { 3.3. Optimal level of } \\
\text { complexity } \\
\text { 3.4. Natural surfaces } \\
\text { 3.5. Engaging features } \\
\text { Risk/Peril } \\
\text { Movement } \\
\text { 3.6. Presence of } \\
\text { Water } \\
\text { 3.7. Sensory stimuli } \\
\text { design } \\
\text { Sensory stimuli: Sight } \\
\text { Sensory stimuli: Hear- } \\
\text { ing } \\
\text { Sensory stimuli: Smell } \\
\text { Sensory stimuli: Touch } \\
\text { Sensory stimuli: Taste } \\
\text { Sensory path }\end{array}$ & $\begin{array}{l}\text { 4.1. Works of Art } \\
\text { 4.2. Monuments } \\
\text { in the park } \\
\text { 4.3. Historic } \\
\text { places } \\
\text { Culture and } \\
\text { connection } \\
\text { to the past } \\
\text { 4.4. Thematic } \\
\text { gardens } \\
\text { 4.5. Personaliza- } \\
\text { tion } \\
\text { 4.6. Animation of } \\
\text { place } \\
\text { 4.7. Community } \\
\text { Engagement } \\
\text { Personalising } \\
\text { the architectural } \\
\text { process } \\
\text { Participation of } \\
\text { all stakeholders, } \\
\text { including inhab- } \\
\text { itants and users } \\
\text { Determining the } \\
\text { rules of conduct } \\
\text { and self- } \\
\text { management } \\
\text { Space for social } \\
\text { contact } \\
\text { - third places } \\
\text { - fourth places }\end{array}$ & $\begin{array}{l}\text { 5.1. Green } \\
\text { Infrastruc- } \\
\text { ture } \\
\text { 5.2. Parks of } \\
\text { Second } \\
\text { (New) Gen- } \\
\text { eration } \\
\text { 5.3. Biodi- } \\
\text { versity } \\
\text { protection } \\
\text { Part of park } \\
\text { not-available } \\
\text { to visitors } \\
\text { Native } \\
\text { plants } \\
\text { Native } \\
\text { animals } \\
\text { Natural } \\
\text { maintenance } \\
\text { methods } \\
\text { 5.4. Sus- } \\
\text { tainable } \\
\text { water man- } \\
\text { agement } \\
\text { Rainwater } \\
\text { infiltration } \\
\text { Irrigation } \\
\text { with non- } \\
\text { potable } \\
\text { water } \\
\text { 5.5. Urban } \\
\text { metabolism } \\
\text { 5.6. Ecologi- } \\
\text { cal energy } \\
\text { sources }\end{array}$ & $\begin{array}{l}\text { 6.1 Sidewalk Infra- } \\
\text { structure- } \\
\text { Width of sidewalk } \\
\text { Evenness of surface } \\
\text { Lack of obstructions } \\
\text { Slope } \\
\text { Sufficient drainage } \\
6.2 \text { General condi- } \\
\text { tions: Maintenance } \\
\text { Overall aesthetics } \\
\text { Street art } \\
\text { Sufficient seating } \\
\text { Perceived safety } \\
\text { Buffering from traffic } \\
\text { Street activities } \\
\text { Vacant lots } \\
6.3 \text { Traffic } \\
\text { Speed } \\
\text { Volume } \\
\text { Number and safety } \\
\text { of crossings } \\
\text { On-street parking } \\
6.4 \text { User Experience } \\
\text { Air quality } \\
\text { Noise level } \\
\text { Sufficient lighting } \\
\text { Sunshine and shade } \\
\text { Transparency of } \\
\text { ground floors of } \\
\text { building }\end{array}$ \\
\hline
\end{tabular}




\section{CONCLUSIONS}

The designed environment based on $3 e$ principles can influence the creation of community engagement, social bonds and social capital. The study revealed that a new category of attributes related to community engagement was missing from both the UNIVERSAL STANDARD FOR THERAPEUTIC PARKS and the UNIVERSAL STANDARD FOR HEALTH PROMOTING PLACES. The literature review and study of selected eco-neighbourhoods confirmed that that category is important and feasible. The standard is an open concept, which should be improved with new attributes when new evidence is available.

\section{STRATEGIE ARCHITEKTONICZNE PROMUJĄCE TWORZENIE WIĘZI SPOKECZNYCH NA TERENIE EKOOSIEDLI W PÓŁNOCNEJ EUROPIE}

\section{WPROWADZENIE}

Architektura i urbanistyka zawsze były postrzegane jako droga do lepszej przyszłości. Misja budowy nowego, ulepszonego środowiska dla ludzi została rozszerzona o zasady zrównoważonego rozwoju. Koncepcja zasad 3e: ekologia - ekorówność - ekonomia opiera się głównie na czynniku ludzkim. Ekologiczne aspekty architektury i urbanistyki wymagają harmonii z naturą i innymi ludźmi. Koncepcja równości zakłada wspólne życie w środowisku, które stymuluje indywidualny rozwój i dobre samopoczucie. Aspekty ekonomiczne obejmują promocję gospodarki krótkich dystansów o obiegu zamkniętym, zapewnienie miejsc pracy mieszkańcom oraz ograniczenie zbędnych wydatków. Stworzenie nowego miejsca do życia powinno wiązać się z budową lepszego społeczeństwa. Wszystkie trzy dynamiki zrównoważonych społeczności: gospodarka, ekologia i sprawiedliwość społeczna są powiązane z kapitałem społecznym. Dzisiaj sposobem na scalenie tej dynamiki w jednym miejscu jest tworzenie ekoosiedli. To, co zaczęło się w połowie XX wieku jako inicjatywa oddolna, dziś staje się coraz bardziej popularne na całej planecie. Istnieją przykłady ekoosiedli wdrożonych i dobrze funkcjonujących we wszystkich częściach świata i na obu półkulach. W tym artykule skupiamy się na aspektach społecznych i znaczeniu równości w projektowaniu i zarządzaniu ekoosiedlami. Pytanie badawcze brzmi: jakie rozwiązania architektoniczne można zastosować, aby stymulować tworzenie przyjaznego środowiska społecznego w ramach zrównoważonej tkanki miejskiej? Wielokrotnie próbowano stworzyć idealne miejsce do życia. Jednak Dragos Stefan Dascalu (2013) zwraca uwage na fakt, że: Jest to prawdziwy paradoks (obecny w wielu, jeśli nie we wszystkich utopiach), że próba stworzenia nowego, doskonałego społeczeństwa prowadzi do przeciwnego, perwersyjnego efektu, polegającego na stworzeniu społeczeństwa totalitarnego, represyjnego, jednorodnego społecznie. Dziś nowym pomysłem na wprowadzenie w życie koncepcji zasad 3e na rzecz dobra ludzi jest tworzenie ekoosiedli. Trzeba jednak wyciągnąć wnioski z przeszłości, że najważniejszymi czynnikami są kapitał społeczny i więzi społeczne związane z zaangażowaniem społecznym.

\section{METODA}

W pierwszej części artykułu zaprezentowano przegląd literatury, a następnie wprowadzenie nowej kategorii do stworzonego przez autorkę uniwersalnego standardu miejsc promocji zdrowia. Pierwsze pytanie badawcze dotyczyło tego, jak zdefiniować kapitał społeczny i więzi społeczne oraz określić wpływ, jaki architektura może mieć na ich tworzenie. Pojęcie kapitału społecznego sięga XIX wieku. Pierre Bourdieu uważał kapitał społeczny za formę kapitału ekonomicznego, który może być akumulowany, przekazywany i odtworzony w czasie (Dascalu, 2013). Robert Putnam argumentuje, że kapitał społeczny jest formą dobra publicznego powiązaną z niższym wskaźnikiem 
przestępczości, wyższym altruizmem i poprawą zdrowia (ibidem, Dascalu, 2013; Putnam, 2000). Dragos Stefan Dascalu (2013) odnosi kapitał społeczny do sieci społecznościowych zbudowanych na zasadzie wzajemności i zaufania. Wymienia upodmiotowienie jednostek, równość społeczną, poziom informacji i wiedzy oraz jakość wcześniejszych doświadczeń kooperacyjnych jako mechanizm, na którym opiera się tworzenie kapitału społecznego. Jednocześnie argumentuje, że architektura rozumiana jako obiekt lub przestrzeń nie mogłaby spełniać tej roli. Forma budowlana, konfiguracje przestrzenne czy architektura rozumiana jako obiekt ma w istocie bardzo niewielki wpływ na kapitał społeczny. Musimy zmienić paradygmat na procesualne podejście do architektury uważanej za dyspozytywną, która może stymulować budowanie opartych na zaufaniu relacji między jednostkami, a tym samym może stymulować pojawienie się kapitału społecznego. Aby pełnić tę rolę, architektura rozumiana jest jako zespół czynników związanych z budową przestrzeni: normy, prawa, użytkowanie, funkcja, proces, praktyka. Tylko dyspozytywne podejście do architektury może mieć znaczenie (Dascalu, 2013). Celem pracy było określenie, w jaki sposób architektura może stymulować zaangażowanie społeczności, tworzenie więzi społecznej i pojawienie się kapitału społecznego.

\subsection{Dyskusja}

Budowanie kapitału społecznego jest procesem narastającym i kumulującym się, co związane jest z rozciągniętą długością procesu (Dascalu, 2013). Jednym z kluczowych czynników tego procesu jest zaufanie, które zależy od szeregu mechanizmów. Dragos Stefan Dascalu (2013) jako najważniejsze wymienił upodmiotowienie jednostek, równość społeczną, poziom informacji i wiedzy oraz jakość wcześniejszych doświadczeń kooperacyjnych. Równość ekonomiczna obejmująca poziom dochodów i standard życia ma fundamentalne znaczenie dla budowania zaufania społeczności. Im bardziej sprawiedliwa jest gospodarka, tym wyższy będzie poziom ogólnego zaufania (Dascalu, 2013). Architektura, chociaż nie jest magią, która mogłaby uczynić dobrych ludzi z negatywnych postaci, może mieć pewien wpływ na ludzkie zachowanie. Forma architektoniczna może w pewnych warunkach zezwalać lub utrudniać określone działania. Nie można go jednak badać niezależnie od całej sieci powiązań (Dascalu, 2013). W literaturze wspomina się o kilku strategiach, które można zastosować, aby ułatwić tworzenie kapitału społecznego:

- Personalizacja procesu architektonicznego

- Udział wszystkich interesariuszy, w tym mieszkańców i użytkowników

- Ustalanie zasad postępowania i samozarządzania

- Przestrzeń do kontaktów społecznych

- Trzecie miejsca

- Czwarte miejsca

\section{Personalizacja procesu architektonicznego}

Aby zaufać komuś, ludzie muszą go poznać. Dragos Stefan Dascalu (2013) stwierdził, że: Aby budować relacje zaufania, wszyscy interesariusze muszą być fizycznie obecni, otwarci na rozwijanie relacji i oferowanie możliwości testowania zaufania. Nie jest to normalne, ponieważ wielu architektów woli określać funkcję w imieniu potencjalnych użytkowników na podstawie dedukcji konieczności. Zwykle interesariusze wolą decydować w imieniu innych osób, co jest dla nich konieczne. W przypadku nowoczesnych ekoosiedli może się to wydawać logiczne, gdyż przyszli mieszkańcy w większości przypadków są nieznani. Jednak są też inni Interesariusze (architekci, samorząd, pośrednicy finansowi, użytkownicy z sąsiednich okolic, budowniczowie, inwestorzy, klienci itp.) Są to interesariusze łatwi do zidentyfikowania i powinni się dobrze poznać. Taki kierunek działania, w którym wszyscy interesariusze współpracują od samego początku procesu inwestycyjnego, nazywany jest Projektowaniem Zintegrowanym i jest znakiem rozpoznawczym operacjonalizacji zasad zrównoważonego rozwoju w architekturze. Oznacza to, że proces musi być tak zaprojektowany, aby interesariusze mogli się spotkać i zaprezentować jako jednostki, a nie jako instytucje (Dascalu, 2013). To wysoce spersonalizowane podejście jest podstawą Projektowania Zintegrowanego. 


\section{Udział wszystkich interesariuszy, w tym mieszkańców i użytkowników}

Kapitał społeczny tworzy się w silnej społeczności, wśród obywateli o wysokim poczuciu wspólnoty. Jedno pozytywne doświadczenie zwykle prowadzi do wyznaczania coraz bardziej ambitnych celów. Obywatele, którzy są świadomi, że mogą coś zdziałać, jeśli pracują razem, budują silniejsze więzi kapitału społecznego. Pojęcie partycypacji społecznej odnosi się do umożliwienia obywatelom uczestniczenia w działaniach organów administracji publicznej oraz wpływu „mniejszości” na decyzje zarządzających (Bednarska-Olejniczak, Olejniczak i Svobodová, 2019). Procesy współuczestnictwa społeczności prowadzą do współodpowiedzialności w podejmowaniu decyzji (Amado i in., 2009). Partycypacja społeczna to proces, w ramach którego społeczne troski, potrzeby i wartości są włączane do procedur decyzyjnych i jako takie wymagają kolejnych etapów procesu (informowanie społeczeństwa, słuchanie opinii publicznej, angażowanie się w rozwiązywanie problemów, zawieranie porozumień). (Bednarska-Olejniczak, Olejniczak \& Svobodová, 2019). Dla tworzenia kapitału społecznego najkorzystniejsze jest uwzględnienie udziału użytkowników od samego początku procesu planowania. Udział społeczności może sprawić, że zasoby obszaru interwencji (ludzkie, naturalne, gospodarcze i kulturowe) będą cenione przez podmioty lokalne, a tym samym staną się podstawą do nowych zrównoważonych działań, rozwoju zatrudnienia i dobrobytu, zachowania wartości przyrodniczych i promowania zaangażowania w tworzenie tożsamości przestrzeni publicznej z większą wrażliwością i odpowiedzialnością społeczną (Amado i in., 2009). Sam udział społeczeństwa wymaga promowania inicjatyw obywatelskich, wzmocnienia pozycji organizacji społecznych i wzmocnienia lokalnej demokracji. (Bednarska-Olejniczak, Olejniczak \& Svobodová, 2019). Może więc obejmować bardzo szeroki wachlarz działań i narzędzi: budżet partycypacyjny, obywatelskie inicjatywy ustawodawcze, działania aktywizujące (pikniki, imprezy kulturalne itp.), badania ankietowe, prace studialne (warsztaty, laboratoria, konsultacje on-line), promocja dobrych praktyk itp.). ustalanie zasad postępowania i samorządności. Organiczny rozwój demokracji oddolnej może stymulować tworzenie wspólnotowego kapitału społecznego. Bezpośredni udział poszczególnych użytkowników w tworzeniu reguł i ich egzekwowaniu jest niezbędny w procesie budowania zaufania (Dascalu, 2013). Bardzo dobrze sprawdza się zarządzanie, które stosuje innowacyjne metody konsultacji, wzmacniające społeczeństwo obywatelskie. Budowa ekoosiedli wymaga stworzenia zintegrowanego systemu zarządzania strategiami miejskimi i programami miejskimi. Powinno być kilka priorytetów. Przykładowo strategia dla Wrocławia 2030 zakłada działania podzielone na siedem priorytetów: mobilność, jakość środowiska i przestrzeni miejskiej, przedsiębiorczość, kreatywna i innowacyjna gospodarka związana z nauką, zdrowi i aktywni mieszkańcy, zarządzanie i otwarte miasto. Jakość środowiska i przestrzeni miejskiej wiąże się między innymi z promowaniem współdzielenia przestrzeni i zwiększaniem bezpieczeństwa w miejscach publicznych. Samorząd otwarcie nawołuje do organicznego rozwoju demokracji oddolnej, zwłaszcza na osiedlach (Bednarska-Olejniczak, Olejniczak \& Svobodová, 2019)

\section{Przestrzeń do interakcji społecznych}

Teoria Raya Oldenburga (1989) wyróżnia pewne kategorie miejsc społecznych: “miejsce pierwsze " to nasze domy, "miejsce drugie" - miejsca pracy dla dorosłych lub szkoły dla dzieci oraza "miejsce trzecie ", które definiuje się jako wybrane miejsca spotkań towarzyskich, ważne dla indywidualnej istoty ludzkiej. „Miejsca trzecie” charakteryzują się radykalnym odejściem od rutyny domu i pracy, inkluzywnością i komfortem społecznym (Simões Aelbrecht 2016). Wśród „miejsc trzecich” możemy wymienić: kościoły, domy kultury, galerie sztuki, kawiarnie, salony kosmetyczne i fryzjerskie odpowiednio dla pań i panów, warsztaty, obiekty sportowe itp. Rolę „miejsca trzeciego” pełnić może też pawilon ogrodowy, wyposażonego w ogrzewane na chłodniejsze dni. Patricia Simões Aelbrecht (2016) dodała kategorię "miejsc czwartych” jako dodatkową kategorię nieformalnych miejsc społecznych, obok "miejsc trzecich”. „Miejsca czwarte” są określane jako miejsca „pomiędzy" pod względem przestrzeni, działań, czasu i zarządzania, a także poczucia otwartości. Są bardziej otwarte, zróżnicowane społecznie i inkluzywne, mogą łączyć nieznajomych. Patricia Simões Ael-brecht definiując „miejsca czwarte” wymieniła tradycyjne przestrzenie publiczne, takie jak ulice i place i inne nieformalne miejsca spotkań w mieście, np .: skrzyżowania ulic, podesty, przystanki autobusowe i poczekalnie oraz progi wejścia do budynków. Dlatego „miejsca czwarte” pozwalają na dodatkowe czynności, pomiędzy działaniami niezbędnymi, takie jak: „obserwowanie ludzi”, cze- 
kanie i „zabijanie czasu”, zachęcające w ten sposób do interakcji między różnymi grupami użytkowników. Ludzie używają tych przestrzeni, aby stać, rozmawiać, siedzieć i obserwować innych ludzi; Dlatego te przestrzenie zwiększają szanse na społeczną interakcję. Majd Al-Homoud i Louis G. Tassinary (2004) przeprowadzili badanie, które dowodzi, że istnieje niewielki zestaw atrybutów elementów zabudowy domów jednorodzinnych - potencjalnych moderatorów wzorców interakcji społecznych. Te dowody badawcze mogą sugerować wytyczne dotyczące projektowania „miejsc czwartych". Al-Hamoud i Tassinary badali strefy przejściowe - obszary pośrednie między domem a sąsiedztwem, fizycznie i psychicznie. Nazywali je lokalizacjami transakcyjnymi, takimi jak podwórko, podjazdy, ścieżki, ganki, wejścia i schody frontowe. Badacze odkryli, że ludzie używają ich jako pomostów między najbliższą lokalną społecznością oraz regulatorów interakcji społecznych. Są postrzegane jako obszary pośrednie między domem a sąsiedztwem, fizycznie i psychicznie. „Miejsca czwarte” - przestrzenie przejściowe są cenne w kontekście osobistego poczucia przynależności, prawdopodobnie ze względu na działania, które mają miejsce $w$ tych przestrzeniach. Jednak, aby połączyć więzi społeczne, przestrzenie przejściowe wymagają znaczników terytorialnych, takich jak zagospodarowanie terenu, dekoracje ( $w$ tym wyposażenie podwórza), znaki i ogrodzenia. Szczególnie nasadzenia i dekoracje zachęcają mieszkańców do interakcji. Obecność markerów terytorialnych oznacza wsparcie społeczne, ponieważ są one początkowymi symbolicznymi mediami interakcji. Markery te ułatwiają nawiązywanie relacji. $Z$ drugiej strony, nadużywanie markerów terytorialnych sprzyja wykluczeniu społecznemu i izolacji. Tak więc badania naukowe sugerują, że dom i podwórko to dwa byty, które należy zaprojektować jako jedną całość, w której każdy z elementów służy sobie nawzajem i razem tworzą całkowicie prywatną, ale dostępną dla mieszkańców przestrzeń. (Al-Hamoud i Tassinary, 2004) Zarówno „miejsca trzecie”, jak i "miejsca czwarte" mają kluczowe znaczenie dla wspierania nieformalnego życia społecznego ekoosiedli (rys. 1 i 2 ).

\subsection{Przykłady eko-osiedli}

Wyniki przeglądu literatury zostały zweryfikowane na terenie istniejących ekoosiedli. Wybrano sześć osiedli, trzy z oficjalnymi certyfikatami, a trzy ocenione przez autorkę za pomocą indywidualnie opracowanej metodyki jako ekoosiedla (Trojanowska, 2020) (Tab. 1).

Tab. 1. Przegląd wybranych dzielnic

\begin{tabular}{|l|l|l|l|}
\hline & CERTYFIKAT & OGÓLNA CHARAKTERYSTYKA & $\begin{array}{l}\text { STRUKTURA } \\
\text { WŁASNOŚć }\end{array}$ \\
\hline $\begin{array}{l}\text { ZAC CLICHY BA- } \\
\text { TIGNOLLES, } \\
\text { PARYŻ }\end{array}$ & ECOQUARTIER & $\begin{array}{l}\text { centralnie położony w gęsto zaludnionej dzielnicy, } \\
\text { centrum wielkiej metropolii, rewitalizacja urbanistyczna } \\
\text { terenów poprzemysłowych }\end{array}$ & $\begin{array}{l}\text { Własność pry- } \\
\text { watna mieszkań i } \\
\text { powierzchni } \\
\text { komercyjnych // } \\
\text { mieszkania } \\
\text { socjalne // wła- } \\
\text { sność publiczna }\end{array}$ \\
\hline $\begin{array}{l}\text { ZAC DOCKS DE } \\
\text { SAINT OUEN, } \\
\text { SAINT OUEN }\end{array}$ & ECOQUARTIER & $\begin{array}{l}\text { podmiejskie peryferie wielkiej metropolii, rewitalizacja } \\
\text { urbanistyczna terenów po przemysłowych }\end{array}$ & $\begin{array}{l}\text { Własność pry- } \\
\text { watna mieszkań i } \\
\text { powierzchni } \\
\text { komercyjnych // } \\
\text { mieszkania } \\
\text { socjalne // wła- } \\
\text { sność publiczna }\end{array}$ \\
\hline $\begin{array}{l}\text { HAMMARBY SJO- } \\
\text { STAD } \\
\text { SZTOKHOLM }\end{array}$ & ECO-CITY & $\begin{array}{l}\text { podmiejskie obrzeża dużego miasta, rewitalizacja } \\
\text { urbanistyczna dawnego terenu przemysłowego }\end{array}$ & $\begin{array}{l}\text { Własność pry- } \\
\text { watna mieszkań i } \\
\text { powierzchni } \\
\text { komercyjnych // } \\
\text { własność pu- } \\
\text { bliczna }\end{array}$ \\
\hline RIVERVIEW & LEED & historyczne centrum miasta, rewitalizacja urbanistycz- & $\begin{array}{l}\text { Własność pry- } \\
\text { watna mieszkań i }\end{array}$ \\
\hline
\end{tabular}




\begin{tabular}{|l|l|l|l|}
\hline GDAŃSK & czas II wojny światowej & $\begin{array}{l}\text { powierzchni } \\
\text { komercyjnych }\end{array}$ \\
\hline $\begin{array}{l}\text { GARNIZON } \\
\text { GDAŃSK }\end{array}$ & NO LABEL & $\begin{array}{l}\text { historyczna dzielnica, rewitalizacja urbanistyczna } \\
\text { terenów powojskowych }\end{array}$ & $\begin{array}{l}\text { Własność pry- } \\
\text { watna mieszkań i } \\
\text { powierzchni } \\
\text { komercyjnych }\end{array}$ \\
\hline $\begin{array}{l}\text { OSIEDLE FI } \\
\text { KRAKóW }\end{array}$ & NO LABEL & $\begin{array}{l}\text { historyczna dzielnica, rewitalizacja urbanistyczna } \\
\text { terenów poprzemysłowych }\end{array}$ & $\begin{array}{l}\text { Własność pry- } \\
\text { watna mieszkań i } \\
\text { powierzchni } \\
\text { komercyjnych }\end{array}$ \\
\hline
\end{tabular}

Wybrane osiedla zostały przeanalizowane przy użyciu wcześniej przygotowanej metodologii (Trojanowska, 2017; 2020), ale włączono do niej nowe atrybutów związanych z zaangażowaniem społecznym.

- Personalizacja procesu architektonicznego

- Udział wszystkich interesariuszy, w tym mieszkańców i użytkowników

- Ustalanie zasad postępowania i samozarządzania

- Przestrzeń do kontaktów społecznych

- Trzecie miejsca

- Czwarte miejsca

Do oceny obecności atrybutów (za pomocą liczb) zastosowano następującą skalę

1 - atrybut był obecny i dobrze wykorzystano jego potencjał,

0,5 - atrybut był obecny, ale zgłoszono zastrzeżenia,

0 - atrybut nie był obecny.

Dodanie wartości 0,5 pozwoliło na doprecyzowanie, czy potencjał atrybutu został w pełni wykorzystany, czy też zastosowano pewne zastrzeżenia (tab. 2).

Tabela 2. Ocena obecności atrybutów związanych z zaangażowaniem społeczności w wybranych dzielnicach

\begin{tabular}{|c|c|c|c|c|c|c|}
\hline & $\begin{array}{l}\text { ZAC CLICHY } \\
\text { BATIGNOL- } \\
\text { LES, } \\
\text { PARYŻ }\end{array}$ & $\begin{array}{l}\text { ZAC DOCKS } \\
\text { DE SAINT } \\
\text { OUEN, } \\
\text { SAINT OUEN }\end{array}$ & $\begin{array}{l}\text { HAMMARBY } \\
\text { SJOSTAD } \\
\text { SZTOKHOLM }\end{array}$ & $\begin{array}{l}\text { RIVE- } \\
\text { RVIEW } \\
\text { GDAŃSK }\end{array}$ & $\begin{array}{l}\text { GARNIZON } \\
\text { GDAŃSK }\end{array}$ & $\begin{array}{l}\text { OSIEDLE FI } \\
\text { KRAKÓW }\end{array}$ \\
\hline \multicolumn{7}{|l|}{$\begin{array}{l}\text { TWORZENIE } \\
\text { MIEJSCA }\end{array}$} \\
\hline $\begin{array}{l}\text { ZAANGAŻOWA- } \\
\text { NIE SPOŁECZNE }\end{array}$ & SUMA (6) & SUMA (6) & SUMA (6) & SUMA $(5,5)$ & SUMA (6) & SUMA $(5,5)$ \\
\hline $\begin{array}{l}\text { Personalizacja } \\
\text { procesu architekto- } \\
\text { nicznego }\end{array}$ & TAK (1) & TAK (1) & TAK (1) & TAK (1) & TAK (1) & TAK (1) \\
\hline $\begin{array}{l}\text { Udział wszystkich } \\
\text { interesariuszy, w } \\
\text { tym mieszkańców i } \\
\text { użytkowników }\end{array}$ & $\begin{array}{l}\text { TAK (1) projek- } \\
\text { towanie party- } \\
\text { cypacyjne, } \\
\text { projektowanie } \\
\text { zintegrowane }\end{array}$ & $\begin{array}{l}\text { TAK (1) projek- } \\
\text { towanie party- } \\
\text { cypacyjne, } \\
\text { projektowanie } \\
\text { zintegrowane }\end{array}$ & $\begin{array}{l}\text { TAK (1) projek- } \\
\text { towanie party- } \\
\text { cypacyjne, } \\
\text { projektowanie } \\
\text { zintegrowane }\end{array}$ & $\begin{array}{l}\text { NIE (0) } \\
\text { mieszkania } \\
\text { na sprzedaż }\end{array}$ & $\begin{array}{l}\text { NIE (0) } \\
\text { mieszkania } \\
\text { na sprzedaż }\end{array}$ & $\begin{array}{l}\text { NIE (0) } \\
\text { mieszkania } \\
\text { na sprzedaż }\end{array}$ \\
\hline $\begin{array}{l}\text { Ustalanie zasad } \\
\text { postępowania i } \\
\text { samozarządzania }\end{array}$ & TAK (1) & TAK (1) & TAK (1) & TAK (1) & TAK (1) & TAK (1) \\
\hline
\end{tabular}




\begin{tabular}{|c|c|c|c|c|c|c|}
\hline $\begin{array}{l}\text { Przestrzeń do } \\
\text { kontaktów społecz- } \\
\text { nych }\end{array}$ & $\begin{array}{l}\text { TAK (1) } \\
\text { szkoła, centrum } \\
\text { kultury }\end{array}$ & $\begin{array}{l}\text { TAK (1) szko- } \\
\text { ła, centrum } \\
\text { kultury }\end{array}$ & $\begin{array}{l}\text { TAK (1) } \\
\text { szkoła, cen- } \\
\text { trum kultury }\end{array}$ & $\begin{array}{l}\text { TAK/NIE } \\
(0,5) \\
\text { tylko pry- } \\
\text { watne ka- } \\
\text { wiarnie i } \\
\text { sklepy }\end{array}$ & $\begin{array}{l}\text { TAK (1) } \\
\text { centrum } \\
\text { kultury }\end{array}$ & $\begin{array}{l}\text { TAK/NIE } \\
(0,5) \\
\text { tylko pry- } \\
\text { watne } \\
\text { kawiarnie i } \\
\text { sklepy }\end{array}$ \\
\hline Miejsca trzecie & $\begin{array}{l}\text { TAK (1) } \\
\text { centrum kultury } \\
\text { prywatne ka- } \\
\text { wiarnie i sklepy }\end{array}$ & $\begin{array}{l}\text { TAK (1) cen- } \\
\text { trum kultury } \\
\text { prywatne } \\
\text { kawiarnie i } \\
\text { sklepy }\end{array}$ & $\begin{array}{l}\text { TAK (1) } \\
\text { centrum kultury } \\
\text { prywatne } \\
\text { kawiarnie i } \\
\text { sklepy }\end{array}$ & $\begin{array}{l}\text { TAK (1) } \\
\text { prywatne } \\
\text { kawiarnie i } \\
\text { sklepy } \\
\text { centra } \\
\text { kultury w } \\
\text { sąsiedztwie } \\
\text { osiedla }\end{array}$ & $\begin{array}{l}\text { TAK (1) } \\
\text { centrum } \\
\text { kultury, } \\
\text { prywatne } \\
\text { kawiarnie i } \\
\text { sklepy }\end{array}$ & $\begin{array}{l}\text { TAK (1) } \\
\text { prywatne } \\
\text { kawiarnie i } \\
\text { sklepy, } \\
\text { centra } \\
\text { kultury w } \\
\text { sąsiedztwie } \\
\text { osiedla }\end{array}$ \\
\hline Miejsca czwarte & $\begin{array}{l}\text { TAK (1) } \\
\text { uniwersalnie } \\
\text { dostępna prze- } \\
\text { strzeń publiczna }\end{array}$ & $\begin{array}{l}\text { TAK (1) } \\
\text { uniwersalnie } \\
\text { dostępna } \\
\text { przestrzeń } \\
\text { publiczna }\end{array}$ & $\begin{array}{l}\text { TAK (1) } \\
\text { uniwersalnie } \\
\text { dostępna } \\
\text { przestrzeń } \\
\text { publiczna }\end{array}$ & $\begin{array}{l}\text { TAK (1) } \\
\text { uniwersalnie } \\
\text { dostępna } \\
\text { przestrzeń } \\
\text { publiczna }\end{array}$ & $\begin{array}{l}\text { TAK (1) } \\
\text { uniwersal- } \\
\text { nie dostęp- } \\
\text { na prze- } \\
\text { strzeń } \\
\text { publiczna }\end{array}$ & $\begin{array}{l}\text { TAK (1) } \\
\text { uniwersal- } \\
\text { nie dostęp- } \\
\text { na prze- } \\
\text { strzeń } \\
\text { publiczna }\end{array}$ \\
\hline
\end{tabular}

\section{DYSKUSJA. WYNIKI}

Nowe atrybuty, zostały dodane do uniwersalnego standardu miejsc promujących zdrowie. Wyniki przeglądu literatury zestawiono z badaniem wybranych przykładów ekoosiedli. Organizacja tego badania została podzielona podobnie jak przegląd literatury, aby uwzględnić strategie, które można zastosować, aby ułatwić tworzenie kapitału społecznego. Badanie to doprowadzi do wniosku, że uniwersalny wzorzec powinien zostać rozszerzony o kategorię atrybutów architektonicznych związanych z tworzeniem więzi społecznych w kategorii 4. Tworzenie Miejsca.

Zaangażowanie społeczności.

- Personalizacja procesu architektonicznego

- Udział wszystkich interesariuszy, w tym mieszkańców i użytkowników

- Ustalanie zasad postępowania i samozarządzania

- Przestrzeń do kontaktów społecznych

- Trzecie miejsca

- Czwarte miejsca

Tab. 1. Uniwersalny wzorzec miejsc sprzyjających promocji zdrowia z nowymi parametrami. Źródło: M.Trojanowska, 2019

\begin{tabular}{|c|c|c|c|c|c|}
\hline \multicolumn{6}{|c|}{ UNIWERSALNY WZORZEC MIEJSC SPRZYJAJACCYCH PROMOCJI ZDROWIA, } \\
\hline \multicolumn{5}{|c|}{$\begin{array}{l}\text { UNIWERSALNY WZORZEC PARKU } \\
\text { O WŁAŚCIWOŚCIACH TERAPEUTYCZNYCH. }\end{array}$} & \multirow[b]{2}{*}{$\begin{array}{l}\text { 6. DOSTĘP DO } \\
\text { PARKU }\end{array}$} \\
\hline $\begin{array}{l}\text { 1. PROJEK- } \\
\text { TOWANIE } \\
\text { UNIWERSAL- } \\
\text { NE }\end{array}$ & $\begin{array}{l}\text { 2. PROGRAM } \\
\text { FUNKCJONALNY } \\
\text { PARKU }\end{array}$ & $\begin{array}{l}\text { 3. STRUKTURA } \\
\text { FUNKCJONALNO- } \\
\text { PRZESTRZENNA }\end{array}$ & $\begin{array}{l}\text { 4. TWORZENIE } \\
\text { MIEJSCA }\end{array}$ & $\begin{array}{l}\text { 5. UWZGLĘD- } \\
\text { NIENIE WY- } \\
\text { MOGÓW } \\
\text { ZRÓWNOWA- } \\
\text { ŻONEGO } \\
\text { ROZWOJU }\end{array}$ & \\
\hline $\begin{array}{l}1.1 \text { Miejsce } \\
\text { Powierzchnia } \\
\text { Lokalizacja } \\
\text { Otaczająca } \\
\text { tkanka miejska }\end{array}$ & $\begin{array}{l}\text { 2.1. Umożliwienie } \\
\text { regeneracji psy- } \\
\text { chicznej i fizycznej } \\
\text { Przestrzenie } \\
\text { naturalnego krajo- }\end{array}$ & $\begin{array}{l}\text { 3.1. Kształtowanie } \\
\text { przestrzeni parku w } \\
\text { zależności od kom- } \\
\text { pozycji urbanistycz- } \\
\text { nej miasta } \\
\text { 3.2. Różṅnorodność }\end{array}$ & $\begin{array}{l}\text { 4.1. Dzieła sztuki } \\
\text { w parku } 4.2 \text {. } \\
\text { Zabytki w parku } \\
\text { 4.3. Związki miej- } \\
\text { sca z historią }\end{array}$ & $\begin{array}{l}\text { 5.1 Włączenie w } \\
\text { system przyrod- } \\
\text { niczy miasta } \\
\text { 5.2. Parki nowej } \\
\text { (drugiej) gene- }\end{array}$ & $\begin{array}{l}6.1 \text { Infrastruktu- } \\
\text { ra ruchu piesze- } \\
\text { go } \\
\text { Szerokość } \\
\text { chodnika }\end{array}$ \\
\hline
\end{tabular}




\begin{tabular}{|c|c|c|c|c|c|}
\hline $\begin{array}{l}1.2 \text { Kontekst } \\
\text { ekologiczny } \\
\text { Jakość gleby } \\
\text { Jakość wody } \\
\text { Jakość powie- } \\
\text { trza } \\
\text { Poziom hałasu } \\
\text { Bioróżnorod- } \\
\text { ność } \\
\text { Formy ochrony } \\
\text { orzyrody } \\
\text { 1.3 Uniwersalna } \\
\text { dostępność } \\
\text { (potrzeby osób } \\
\text { o ograniczonej } \\
\text { sprawności) } \\
\text { 1.4 Dostępność } \\
\text { oarku } \\
\text { Odległość dla } \\
\text { ootencjalnych } \\
\text { użytkowników } \\
\text { Transport pu- } \\
\text { oliczny } \\
\text { Drogi piesze do } \\
\text { oarku }\end{array}$ & $\begin{array}{l}\text { brazu } \\
\text { Zielona polana } \\
\text { Miejsca odpo- } \\
\text { czynku w słońcu i } \\
\text { w cieniu } \\
\text { Miejsca odpo- } \\
\text { czynku w ciszy i } \\
\text { samotności } \\
\text { Możliwość obser- } \\
\text { wacji innych Ludzi } \\
\text { Możliwość obser- } \\
\text { wacji zwierząt } \\
\text { 2.2. Sprzyjanie } \\
\text { kontaktom spo- } \\
\text { tecznym } \\
\text { Organizacja im- } \\
\text { prez w parku } \\
\text { Miejsce spotkań w } \\
\text { grupie } \\
\text { 2.3. Wspieranie } \\
\text { aktywności fizycz- } \\
\text { nej } \\
\text { Infrastruktura } \\
\text { sportowa } \\
\text { Infrastruktura } \\
\text { rekreacyjna } \\
\text { Ogrody wspólno- } \\
\text { towe } \\
\text { 2.4. Zaspokojenie } \\
\text { podstawowych } \\
\text { potrzeb użytkow- } \\
\text { ników } \\
\text { Bezpieczeństwa } \\
\text { (obecność pra- } \\
\text { cowników ochro- } \\
\text { ny, czystość, } \\
\text { utrzymanie, etc.) } \\
\text { Miejsca do sie- } \\
\text { dzenia i odpo- } \\
\text { czynku } \\
\text { Schronienia } \\
\text { Toaleta } \\
\text { Woda do picia } \\
\text { Jedzenie (możli- } \\
\text { wość zakupu } \\
\text { jedzenie w parku } \\
\text { lub w bezpośred- } \\
\text { nim sąsiedztwie) }\end{array}$ & $\begin{array}{l}\text { architektoniczna } \\
\text { otoczenia } \\
\text { Punkty orientacyjne } \\
\text { Struktura połączeń } \\
\text { przestrzeni we- } \\
\text { wnętrznych } \\
\text { Otwarcia widokowe } \\
\text { na długie osie kom- } \\
\text { pozycyjne } \\
\text { Prowadzenie ścieżek } \\
\text { widokowych } \\
\text { Przesłonięte elemen- } \\
\text { ty sceny, } \\
\text { Wrażenie tajemni- } \\
\text { czości } \\
\text { Kadrowanie widoku } \\
\text { Ludzka skala } \\
\text { 3.3. Optymalny } \\
\text { stopień skompliko- } \\
\text { wania } \\
\text { 3.4. Naturalna na- } \\
\text { wierzchnia } \\
\text { 3.5. Elementy przy- } \\
\text { kuwające uwage } \\
\text { Kontrolowana trud- } \\
\text { ność } \\
\text { Wrażenie ruchu } \\
\text { 3.5. Zbiornik wodny } \\
\text { w parku } \\
\text { 3.6. Projektowanie } \\
\text { oddziaływania sen- } \\
\text { sorycznego } \\
\text { Oddziaływanie sen- } \\
\text { soryczne: wzrok } \\
\text { Oddziaływanie sen- } \\
\text { soryczne: słuch } \\
\text { Oddziaływanie sen- } \\
\text { soryczne: węch } \\
\text { Oddziaływanie sen- } \\
\text { soryczne: dotyk } \\
\text { Oddziaływanie sen- } \\
\text { soryczne: smak } \\
\text { Ścieżka sensoryczna }\end{array}$ & $\begin{array}{l}\text { Dziedzictwo } \\
\text { kulturowe i związ- } \\
\text { ki z przeszłością } \\
\text { 4.4. Ogrody tema- } \\
\text { tyczne } \\
\text { 4.5. Możliwość } \\
\text { personalizacji } \\
\text { przestrzeni parku } \\
\text { 4.6. Animacja } \\
\text { przestrzeni parku } \\
\text { 4.7. Zaangażo- } \\
\text { wanie społeczne } \\
\text { Personalizacja } \\
\text { procesu architek- } \\
\text { tonicznego } \\
\text { Udział wszystkich } \\
\text { interesariuszy, w } \\
\text { tym mieszkańców } \\
\text { i użytkowników } \\
\text { Ustalanie zasad } \\
\text { postępowania i } \\
\text { samozarządzania } \\
\text { Przestrzeń do } \\
\text { kontaktów spo- } \\
\text { łecznych } \\
\text { o Trzecie miejsca } \\
\text { o Czwarte miejsca }\end{array}$ & $\begin{array}{l}\text { racji } \\
\text { 5.3. Ochrona } \\
\text { bioróżnorodno- } \\
\text { ści } \\
\text { Wydzielenie } \\
\text { fragmentu parku } \\
\text { z ograniczonym } \\
\text { dostępem dla } \\
\text { ludzi } \\
\text { Dobór roślin } \\
\text { siedliskowych } \\
\text { Troska o rodzi- } \\
\text { me zwierzęta } \\
\text { Naturalne meto- } \\
\text { dy utrzymania } \\
\text { parku } \\
\text { 5.4. Ochrona } \\
\text { zasobów wody } \\
\text { pitnej } \\
\text { Infiltracja wody } \\
\text { deszczowej } \\
\text { Wykorzystywa- } \\
\text { nie do podlewa- } \\
\text { nia wody nieuz- } \\
\text { datnianej } \\
\text { 5.5. Metabolizm } \\
\text { miejski } \\
\text { 5.6. Wykorzy- } \\
\text { stywanie ekolo- } \\
\text { gicznych źródeł } \\
\text { energii }\end{array}$ & $\begin{array}{l}\text { Równa na- } \\
\text { wierzchnia } \\
\text { Brak utrudnień } \\
\text { Nachylenie } \\
\text { Zagospodaro- } \\
\text { wanie wody } \\
\text { deszczowej } \\
6.2 \text { Ocena } \\
\text { ogólna } \\
\text { Utrzymanie } \\
\text { Estetyka } \\
\text { Sztuka w prze- } \\
\text { strzeni ulicy } \\
\text { Wystarczająca } \\
\text { ilość i jakość } \\
\text { miejsc do sie- } \\
\text { dzenia } \\
\text { Percepcja bez- } \\
\text { pieczeństwa } \\
\text { Buforowanie } \\
\text { ruchu ulicznego } \\
\text { Aktywność na } \\
\text { ulicy } \\
\text { Pustostany } \\
6.3 \text { Ruch pojaz- } \\
\text { dów } \\
\text { Prędkość } \\
\text { Natężenie ruchu } \\
\text { llość i bezpie- } \\
\text { czeństwo } \\
\text { przejść pieszych } \\
\text { Parkowanie na } \\
\text { ulicy } \\
6.4 \text { Jakość } \\
\text { użytkowania } \\
\text { Jakość powie- } \\
\text { trza } \\
\text { Wystarczające } \\
\text { oświetlenie } \\
\text { Poziom hałasu } \\
\text { Nasłonecznienie } \\
\text { i zacienienie } \\
\text { Przezierność } \\
\text { kondygnacji } \\
\text { przyziemia }\end{array}$ \\
\hline
\end{tabular}

\section{WNIOSKI}

Zaprojektowane w oparciu o zasady 3e środowisko może wpływać na budowanie zaangażowania społecznego, więzi społecznych i kapitału społecznego. Badanie ujawniło, że zarówno w uniwersalnym standardzie dla parków terapeutycznych, jak i w uniwersalnym standardzie miejsc promowania zdrowia brakowało kategorii atrybutów związanych z zaangażowaniem społecznym. Przegląd literatury i badanie wybranych ekoosiedli potwierdziło, że kategoria ta jest ważna i możli- 
wa do sprawdzenia. Standard jest koncepcją otwartą, którą należy ulepszać o nowe atrybuty, w miarę jak dostępne będą nowe dowody naukowe.

\section{BIBLIOGRAPHY}

Al-Hamoud M., Tassinary L.G. 2004 Social interactions at the neighborhood-level as a function of external space enclosure Journal of Architectural and Planning Research, 21:1 (Spring, 2004)

Amado M. P., Santos C. V., Moura E. B, Silva V.G. (2009) Public Participation in Sustainable Urban Planning World Academy of Science, Engineering and Technology 53

Bednarska-Olejniczak D., Olejniczak J., Svobodová L. (2019) Towards a Smart and Sustainable City with the Involvement of Public Participation-The Case of Wroclaw Sustainability 2019, 11, 332; doi:10.3390/su11020332

Dascalu D. 2013 Architecture as Tool for Building Social Capital Acta Technica Napocensis: Civil Engineering \& Architecture Vol. 56 No 3 (2013) 204-220, available online: https://www.researchgate.net/publication/260810358 Architecture as Tool for Building Social Capital, retrived on: 2020.12.30

Oldenburg, R 1989 The Great Good Place: Cafes, Coffee Shops, Community Centers, Beauty Parlors, General Stores, Bars, Hangouts, and How They Get You Through the Day. New York: Paragon House

Putnam R, 2000 Bowling Alone, The Collapse and Revival of the American Community, New York, Simon\&Schuster

Simões Aelbrecht P. 2016. 'Fourth places': the contemporary public settings for informal social interaction among strangers, Journal of Urban Design, 21:1, 124-152, DOI: 10.1080/13574809.2015.1106920

Trojanowska M. 2017 Parki i ogrody terapeutyczne Wydawnictwo Naukowe PWN, Warszawa

Trojanowska M., Sas-Bojarska A. 2018 Health-affirming everyday landscapes in sustainable city. Theories and tools, Architecture Civil Engineering Environment Journal, ACEE, vol. 11(3), 2018, pp. 53-61, doi:10.21307/ACEE-2018-037

Trojanowska M., 2020 Therapeutic Qualities and Sustainable Approach to Heritage of the City. The Coastal Strip in Gdańsk, Poland, Sustainability 2020, 12(21), 9243; https://doi.org/10.3390/su12219243

Trojanowska M. 2020 Poszukiwanie standardu projektowania ekoosieldi w Polsce. Wydawnictwa Uczelniane UTP w Bydgoszczy

\section{AUTHOR'S NOTE}

Monika Trojanowska is an architect, urbanist and assistant professor at UTP University of Science and Technology in Bydgoszcz. Her research interests include: therapeutic landscapes, econeighborhoods and the theory of modern architecture.

\section{O AUTORZE}

Monika Trojanowska jest architektem, urbanistą i adiunktem na Uniwersytecie TechnologicznoPrzyrodniczym w Bydgoszczy. Zajmuje się problematyka wykorzystania terapeutycznych właściwości krajobrazu w projektowaniu zielonych przestrzeni publicznych, projektowaniem ekoosiedli oraz teorią architektury współczesnej.

Contact | Kontakt: monika.trojanowska@utp.edu.pl 